\title{
The role of customer orientation in improving services in public administration
}

\section{Introduction}

The dynamics of socio-economic development, information technology and globalization have brought about many changes in the organization and management of the public sector over recent years. Particularly noticeable is a significant increase in awareness and demands of society for public institutions, forcing such organizations to change their aspirations, move away from their heavily bureaucratic approach to administration and focus on improving the quality of services. Public administration in many countries increasingly recognizes the need for continuous quality improvement of the services provided and an ever more rapid response to the growing needs and demands of customers. Broadly speaking, there is now a need to manage customer satisfaction in the face of a dilemma; the requirement to provide services at the highest level whilst at the same time facing the need to cut government expenditure.

In this context, incorporating customer

Ph.D. Anna Ludwiczak University of Zielona Gora Department of Economy \& Management orientation is of particular importance to public administrations. This is one of the basic principles of quality management, referred to often in both the industry standard ISO 
9001:2009 and the concept of Total Quality Management (TQM). Considering, therefore, the issue of contemporary management, a public administration unit should have regard to the use of customer orientation, both external and internal, to best adapt ongoing activities, tasks and processes to the current needs, expectations and requirements of their customers or clients. The basis and the first step of directing activities to satisfy the needs and expectations of the customer should be their identification. The aim of the research presented in the article was therefore to diagnose the application of customer orientation in public administration offices.

\section{The customer in public administration}

In undertaking the analysis of customer orientation in the context of public administration, it is necessary to start by defining the customer in this sector. Such a task is much more difficult in this environment than in commercial enterprises. In Poland, several synonymous terms may be used to replace the term 'customer'. In the same offices, the term 'customer' is often replaced with the words 'petent' (English: suppliant), 'interesant' (English equivalent: client) or 'strona' (English: party).

A 'petent' is "a man seeking something, in the form of a request presented to the office, court, etc. The petent is the one who needs something; he makes a request or demand." ( Kopaliński 1990, p 392). Colloquially 'interesant' can be used to describe a person who has a 'deal' to carry out or business to attend to. In turn, according to the Code of Administrative Procedure, a 'strona (party)' is "anyone concerned with a legal interest or obligation, or who requests a function of a governmental organization due to a legal interest or duty. Parties may be both natural persons and legal persons, and when it comes to state and local government agencies and community organizations, include an organization without legal personality" (Act of 14 June 1960, The Code of Administrative Procedure, OJ 1960.30.168, Article 28 and 29) . According to PN- EN ISO 9000:2006 (2006, p 31), the client is "an organization or person who receives a product", where in the case of public administration device, this may be specific public service.

Public Services, according to M. Zawickiego, S. Mazur and J. Bober (2004, p 16) include public goods in respect that it is impossible to exclude anyone from using them. They are goods, since we expect a certain quality - regardless of the number of people using them (each new consumer does not infringe the rights of others). Public services therefore display an essential element that 
distinguishes them from commercial services, namely that every citizen has a right to them, and most of them are provided free of charge. Service providers are different public entities, which can include, amongst others: budgetary units (including offices), budgetary establishments and economic support offices. The Institutional Development Program implemented by the Polish government in 2000-2004 within the framework of the Rural Development Plan adopted the following classification of public services (Zawicki, Mazur 2004, p 56):

- administrative services (e.g. issuing of documents on request, licensing, and decisions within the meaning and mode of the Code of Administrative Procedure, issuance of permits and licenses related to economic activities regulated by the State),

- social services (e.g. health, education and upbringing, assistance and welfare, public safety),

- technical services (e.g. water management - water supply and sewerage, waste management and the maintenance of order and cleanliness, public green space). With reference to the above-described classification, two main types of customers can therefore be distinguished, i.e. customers of public administration (users of technical and social services) and customers of public administration (users of administrative services).

M. Bugdol (2008, p 275), in addition, divided individual customers into the following:

- experienced recipients - people who know how and why to use the services offered,

- unexperienced recipients-people who use the services on receipt of notices such as the need to pay the tax,

- clients "of necessity" (eg clients of taxation authorities),

- "politicized" customers (eg, presidents of associations, heads of local parties and groups, etc.).

To sum up, the essential difference between public customers and clients of commercial organizations is that the former through, inter alia, the fact that they are taxpayers, are essentially "co-owners" of these units. They should therefore be able to not only passively use the services provided to them, but also have peer influence over their functioning.

\section{Customer orientation in public administration}

Customer orientation lies in the fact that all actions should take into account the needs, requirements and expectations of customers. The three definitions are often 
used interchangeably, but have different meanings. According to the dictionary of the Polish language, 'need' is something that is necessary for a normal existence, or for proper functioning. 'Requirement' is a condition or set of conditions, under which someone or something has to respond. In turn, 'expectation' is something that you want and expect ( http://www.sjp.pwn.pl, date of access : 01.10.2014 ). In relation to the services provided by public administrations, it can therefore be concluded that need will be met through conferment of services to the client (e.g. issuing an identity card), requirements will be met provided the service rendered meets specific parameters (is done properly, in accordance with the regulations, is not defective, etc.), while expectations are met when the service is rendered to the recipient in the way in which the customer wishes to be served, and as expected (e.g. nice atmosphere, corresponding to the possibility of the client receiving services, etc.). Today, there are many concepts that hold customer orientation as a fundamental principle. In the context of the ongoing empirical research by the author, in which the implementation of a quality management system compliant with the requirements of BS EN ISO 9001:2009 by the Marshall's Office is analyzed, the following description focuses on customer orientation in terms of the ISO standards and Total Quality Management (TQM), of which at least some elements could be successfully used in public administration towards its continuous improvement. There are many examples of implementation of these concepts as well as their reengineering in the public sector (Otenyo, Lind 2006, pp. 619-620; Wawak, 1998, p 44; Bowman, Hallein, 1998, pp. 114-130; Robertson, Ball 2002, pp. 387-402), showing the importance of the issue and the need to focus on public managers.

The terminology of both standard BS EN ISO 9000:2006 (2006, p.7) and BS EN ISO 2004:2010 (p. 85) describe customer orientation as the first of the eight quality management principles that managers can use to improve the functioning of their units. According to the standards, organizations are dependent on their customers and should therefore seek to understand the current and future needs of their customers in order to meet their requirements and even surpass them. The second of these standards also highlights the three key benefits of customer orientation. The most important of these, from the point of view of public administration, is to increase the efficiency of resource organizations to improve customer satisfaction.

The most important, however, from the point of view of public administration bodies that have implemented quality management systems in accordance with the requirements of BS EN ISO 9001:2009 (2009, p 19), is there are provisions contained in section 5.2 of this standard: "Top management shall ensure that 
customer requirements are identified and met in order to enhance customer satisfaction." Moreover, in accordance with the requirements of this standard (BS EN ISO 9001:2009, pp. 25-27) organizations, in the case of processes associated with the customer, should:

- identify product requirements established by the customer, including those relating to delivery and post-delivery activities,

- achieve maintenance requirements for the product. Organizations should, prior to delivery of the product, inspect the requirements related to the product and establish whether they are able to fulfil them,

- communicate with customers, i.e. to determine and implement effective arrangements for communicating with customers regarding: information on the product, handling clients such as the conclusions and feedback from the client, including complaints.

Moreover, in accordance with BS EN ISO 9001:2009 (2009, p 35) for monitoring and measuring, one measure of the quality management system should be the results of the analysis of information relating to customer perception in order to meet the organization's requirements. For this purpose, the organization should have in place specific methods for obtaining and using this information.

A broader look at the issue of customer orientation is presented by Total Quality Management (TQM). According to TQM, customer orientation should be part of the strategy of the organization and be considered at the stage of formulating its vision. It further stresses the role of not only external customers but also internal customers (the so-called quality chain), where employees are treated as internal suppliers and recipients, who must produce a certain value at all stages of the process.

E. Konarzewska-Gubała (2006, p 154) further emphasizes that successful organizations based on external customer satisfaction depend to a large extent on the satisfaction of employees, or internal customers. TQM emphasizes the need to study both the tastes and preferences of customers and measure their satisfaction, for example, with the services provided.

\section{Results of studies on the use of customer orientation in selected government offices}

In this study, research was conducted by the author with a diagnosis application in the offices of local administration (for example Marshal's Offices) of customer orientation in the context of services provided by the offices of administrative services. The study was carried out in the years 2008-2012 and forms part of

The role of customer orientation in improving services in public administration 
research conducted for the author's doctoral dissertation. The research process was carried out in three selected government offices, which have implemented a quality management system compliant with the requirements of PN-EN ISO 9001:2009.

The research consisted of conducting a self-assessment in accordance with the applicable requirements of the standard PN-EN ISO 9004:2001 and an indepth study of documentary evidence. The aim of the study was therefore to determine the level of maturity of systems in terms of the offices meeting the requirements of PN-EN ISO 9001:2009 with respect to customer orientation. The self-assessment exercise used a scale from 1 to 5 for the maturity level of functioning in accordance with BS EN ISO 9004:2001, where the digits represent the following levels:

- level 1 - no formal approach (No clear evidence found that the system operates according to the standards),

- level 2 - passive approach (A formal system exists and operates, however, there is a lack of visible commitment from the top management),

- level 3 - stable, formal systems approach (system functions are performed, quality objectives are achieved, initial ideas for improvement can be seen.),

- level 4 - focus on continuous improvement (efforts of the employees in the improvement of the system are becoming visible. The authority has evidence that the system is effective and efficient),

- level 5 - best achievement in the class (i.e. the solutions can be considered as world-class).

Table 1 shows the averaged results of self-assessments made by the two groups of respondents, i.e. proxies for quality management systems and managers, with regard to customer orientation.

The results of self-assessments, documentation and in-depth studies conducted to examine offices in terms of their approach to customer orientation oscillate between the passive and stable formal system approach, with an emphasis on certain points of continuous improvement. Studies have shown slight differences in assessments between proxies and managers. The higher scores attributed to proxies, who are also experts in the field for quality management systems in the surveyed offices may result from various causes. One of them may be the subjectivity of the assessment carried out by proxies, resulting from their position - i.e. being the person responsible for the system's proper functioning. Differences in the assessment of executives in relation to proxies may also result from lack of knowledge regarding the initial implementation of the systems. A lack of employee awareness of the rules of the system and its role in 
improving the quality of the organization will result in a lower evaluation of the system than that of agents who are familiar with the actions undertaken within the framework of the improvement of the QMS.

Table 1. Results of self-assessment in the application of customer orientation

\begin{tabular}{|c|c|c|c|c|c|c|c|}
\hline \multirow[t]{3}{*}{ No. } & \multirow{3}{*}{$\begin{array}{l}\text { Action } \\
\text { Research Unit } \\
\text { Evaluating person }\end{array}$} & \multicolumn{6}{|c|}{ Level of maturity } \\
\hline & & \multicolumn{2}{|c|}{ Office 1} & \multicolumn{2}{|c|}{ Office 2} & \multicolumn{2}{|c|}{ Office 3} \\
\hline & & $\begin{array}{l}\text { QMS } \\
\text { Pro- } \\
\text { xy }\end{array}$ & $\begin{array}{l}\text { Execu- } \\
\text { ti-ve } \\
\text { ma- } \\
\text { nage- } \\
\text { ment }\end{array}$ & $\begin{array}{c}\text { QMS } \\
\text { Pro- } \\
\text { xy }\end{array}$ & $\begin{array}{c}\text { Exe- } \\
\text { cuti- } \\
\text {-ve } \\
\text { ma- } \\
\text { nage- } \\
\text { ment }\end{array}$ & $\begin{array}{l}\text { QMS } \\
\text { Proxy }\end{array}$ & $\begin{array}{l}\text { Execu- } \\
\text { ti-ve } \\
\text { mana- } \\
\text { gement }\end{array}$ \\
\hline \multicolumn{8}{|c|}{ Management Responsibility } \\
\hline & Internal and external customers & 3,00 & 2,90 & 3,00 & 3,50 & 3,30 & 3,30 \\
\hline 1. & $\begin{array}{l}\text { To what extent does the office determine } \\
\text { the customer's needs and are they are } \\
\text { continuously and systematically identified? }\end{array}$ & 2,00 & 2,75 & 3,00 & 3,60 & 3,00 & 3,00 \\
\hline 2. & $\begin{array}{l}\text { To what extent are customer needs are } \\
\text { being met? }\end{array}$ & 3,00 & 3,00 & 3,00 & 3,80 & 4,00 & 4,00 \\
\hline \multirow[t]{2}{*}{3.} & $\begin{array}{l}\text { To what extent has the office identified and } \\
\text { met the needs of employees? }\end{array}$ & 4,00 & 3,00 & 3,00 & 3,00 & 3,00 & 3,00 \\
\hline & Quality policy & 4,00 & 4,00 & 3,00 & 3,80 & 4,00 & 4,00 \\
\hline \multirow[t]{2}{*}{4.} & $\begin{array}{l}\text { To what extent does the quality policy } \\
\text { provide an understanding of customer } \\
\text { needs and expectations? }\end{array}$ & 4,00 & 4,00 & 3,00 & 3,80 & 4,00 & 4,00 \\
\hline & $\begin{array}{l}\text { Responsibility, authority and } \\
\text { communication }\end{array}$ & 3,00 & 3,58 & 3,67 & 3,67 & 4,00 & 4,00 \\
\hline 5. & $\begin{array}{l}\text { To what extent does top management } \\
\text { ensure dissemination throughout the } \\
\text { organization of awareness of customer } \\
\text { requirements? }\end{array}$ & 3,00 & 3,50 & 4,00 & 3,60 & 4,00 & 4,00 \\
\hline \multicolumn{8}{|c|}{ Service delivery } \\
\hline & Service delivery planning & 3,00 & 2,25 & 3,00 & 4,00 & 3,00 & 3,33 \\
\hline
\end{tabular}




\begin{tabular}{c|l|l|l|l|l|l|l}
\hline 6. & $\begin{array}{l}\text { To what extent were the customer's } \\
\text { requirements determined and recorded } \\
\text { in relation to the services provided by the } \\
\text { office, and were they are monitored? }\end{array}$ & 3,00 & 2,25 & 3,00 & 4,00 & 3,00 & 3,33 \\
\hline & Customer related processes & 3,00 & 2,75 & 2,50 & 3,55 & 3,00 & 3,50 \\
\hline 7. & $\begin{array}{l}\text { To what extent were the needs of } \\
\text { customers taken into account in the design } \\
\text { process associated with the client? }\end{array}$ & 3,00 & 3,00 & 2,00 & 3,40 & 1,00 & 3,00 \\
\hline 8. & $\begin{array}{l}\text { To what extent has the implementation of } \\
\text { the quality system affected communicate } \\
\text { with the customer? }\end{array}$ & 3,00 & 3,00 & 3,00 & 3,60 & 4,00 & 3,67 \\
\hline 9. & $\begin{array}{l}\text { Is customer feedback customer (eg } \\
\text { complaint) considered and taken into } \\
\text { account in the process of improvement of } \\
\text { the quality system? }\end{array}$ & 3,00 & 3,00 & 3,00 & 4,00 & 4,00 & 4,00 \\
\hline 10. & $\begin{array}{l}\text { What information does the customer have } \\
\text { access to concerning the process in which } \\
\text { he is involved (eg, through access to the } \\
\text { visualization of the process) }\end{array}$ & 3,00 & 2,00 & 2,00 & 3,20 & 3,00 & 3,33 \\
\hline 13. & How is customer satisfaction surveyed? & 3,00 & 2,50 & 2,00 & 3,20 & 4,00 & 3,67 \\
\hline
\end{tabular}

Source: own work

As previously explained, offices which have implemented quality management systems in accordance with the requirements of BS EN ISO 9001:2009 should ensure that customer requirements are defined, and also seek to understand their current and future needs and expectations. In-depth research consisting of documentation and unstructured interviews with proxies for quality management systems in the government offices surveyed indicated that the surveys were conducted on the basis of the measurement of customer satisfaction 
with the services provided (e.g. the complaints register, grievances, questionnaires assessing the authority made available on the website), rather than on action take on attempts to identify their needs, requirements and expectations. During the identification process, the implementation of administrative services to the greatest extent focused on the legal requirements, which research has shown, represents a major barrier and greatly limits the possibility to tailor services to customer requirements.

\section{Conclusions}

At the design stage for service delivery processes at administrative offices, it is necessary to identify the client, which may be collective (e.g., businesses, organizations and other government agencies) or individual. After identifying clients who are recipients of the service, and thus the participants and beneficiaries of the process of its implementation, it is necessary to determine their needs, requirements and expectations. This is a very difficult task due to the customer and his "nature” as well as due to the nature of the services provided. Customer requirements for individual services may significantly differ from each other depending on who is the recipient (a person with a disability or another entrepreneur may have different needs) and the nature of the service itself (e.g. for the customer who wishes to obtain a building permit, the time of the service and the degree of its complexity is of greatest importance, while for the customer who wishes to change domicile, easy access to the service is a priority, that is, for example, diversity of inputs and outputs of the process). However, there are also requirements imposed by the common nature of services provided by the office. Every customer expects professional, efficient, courteous and impartial service. During the design process to determine the needs, requirements and expectations with respect to the service, it is possible to act in two ways: to put yourself in the role of client and consider its course from his point of view or to examine the target group of customers using the available methods and research tools. Proper design of processes for customer orientation is a very difficult task, as shown by often superficially treated studies conducted by the authorities implementing the quality management system. This may result in both of the aforementioned difficulties associated with the identification of customer expectations as well as excessive focus on legal aspects. Whilst legal considerations are undisputedly one of the pillars on which the process must be built, the other factors that should influence its course must not be forgotten about.

The role of customer orientation in improving services in public administration 
An essential component of a well-functioning quality management system compliant with BS EN ISO 9001:2009 is continuous improvement of quality, especially the quality of the processes directly related to the external customer. This improvement is not possible without conducting continuous monitoring of rapidly changing customer expectations and determining the level of satisfaction with the services provided. Key factors affecting customer expectations are mentioned in literature (Prime Minister's Office 2008, p 21): personal needs, previous experience, "word of mouth" information, and formal and the hidden messages about the service. Formal transfer lies in the fact that the customer can receive service information through means such as the website, flyers, signage, etc., and includes hidden messages such as the appearance of buildings, office equipment (a customer seeing a well- equipped office can expect a higher quality of service). These factors are subject to constant change. For example a client who has so far benefited from some service in the office may have heard from a friend in another province that the same service is performed there faster and more efficiently, resulting in increased expectations. Therefore, in order to meet these expectations good monitoring of customer satisfaction is necessary.

There are many possibilities for the monitoring of customer satisfaction in public administration. Noteworthy here, amongst others, is Servqual (Service Quality - the quality of service), a tool for measuring the quality of service which is based on an assessment of the perceptions and expectations of customers (.i.e, examining the difference that exists between what the customer expects from a service and what is believed to have been received). The possibility of using this tool in the public sector has been indicated by, inter alia, M. Donnelly, JF Dalrymple, M. Wisniewski and A. C. Curry (1995, p 271 ) and R. Wolniak and B. Skotnicka - Zasadzień (2009). It is a tool much more difficult to apply than the customer satisfaction survey method employed by many offices, which focuses primarily on assessing client perception, but does not verify his expectations. The problem with the implementation of this tool could also be due to the relatively strong expansion of the questionnaire. M. Bugdol ( 2008, p 202) as a weakness of this method mentions that customers do not always have good estimate your expectations. Firstly, some people do not know how the service should be performed. In addition, such approaches have a comparative scale and the elements (statements) contained in five dimensions are subjective. Some items are difficult to estimate (confidence, courtesy, etc.) and the relationships and dependencies between dimensions of quality may not be known, (although these compounds 
have been studied). Despite these difficulties, this method can be a valuable tool for measuring the quality of services provided by public administrations with proper adjustment to the nature of the specific business factors affecting customer satisfaction.

In addition to the above presented Servqual tool, there are many other methods and tools, which can be used to research customers. An interesting solution is the use of mystery shopping, which consists of examining the quality of the service in the client role. It is also possible to employ various kinds of surveys and interviews (targeted to both customers and employees, so-called „First contact”). To measure the quality of services provided, Bugdol M. (2008, pp. 211-214) also proposes the technique of critical events. Solutions in this area can also be found in the guidance issued by the EUPAN for customer satisfaction management (Prime Minister's Office 2008, pp. 51-86). This publication mentions as methods of measuring customer satisfaction, among others:

- client map describing experiments involving the customer during their interaction with the service (this is subjected to analysis, in this case the process of the service),

- consultations with target groups to whom the service is addressed, panels of customers (ie, selected individuals from customers who have agreed to participate in periodic surveys),

- group interviews and focus groups,

- cards from citizens / customers (consisting of the undertaking / declaration of offices to provide services within a particular card in the standard),

- Open Space Technology (consisting of organizing open meetings to discuss issues such as the delivery of certain services),

- ethnography (i.e., using all possible scientific methods to understand human behaviour and culture),

- segmentation (involving, inter alia, identifying groups of customers with common needs).

Studies conducted in selected government offices indicate that customer satisfaction is carried out in a limited fashion and mostly at the level of the entire office, whilst customer satisfaction of individual processes is not measured. This is a fundamental drawback of these systems, because it shows only an average assessment of the entire office and does not give a complete picture of the assessment of the quality of individual processes. In addition, there are many other ways of obtaining information about the customer and their needs and expectations. This gives the authorities a number of possibilities for the

The role of customer orientation in improving services in public administration 
measurement of needs, requirements and expectations as well as satisfaction with services both in the office as a whole and for specific processes. The European experience in the field of application of these measurements demonstrates that it is an extremely important part of a properly functioning quality management system and positively affects the quality of services provided.

\section{Abstract}

The role of customer orientation in improving services in public administration

The article presents the problem of improvement in public administration offices in one of the most important current principles of quality management - customer orientation in the context of the functioning of these units in quality management systems compliant with the requirements of BS EN ISO 9001:2009. The results of the author's research in the use of this orientation in selected government offices are presented. The article explores the deficiencies that occur in the offices surveyed in this respect and presents examples of possible methods and tools for the study of the needs, requirements and expectations of customers and techniques for the measurement of their satisfaction that may be used in public administration

Key words: customer orientation, public administration, quality management system.

\section{Streszczenie}

\section{Rola orientacji na klienta $w$ doskonaleniu usług $w$ administracji publicznej}

W artykule przedstawiono problematykę stosowania w urzędach administracji publicznej jednej $\mathrm{z}$ najważniejszych obecnie zasad zarządzania jakością - orientacji na klienta w kontekście funkcjonowania $\mathrm{w}$ tych jednostkach systemów zarządzania jakością zgodnych z wymaganiami normy PN-EN ISO 9001:2009. Przedstawiono wyniki badań autorki w zakresie stosowania tej orientacji $\mathrm{w}$ wybranych urzędach marszałkowskich. Zwrócono uwagę na braki $\mathrm{w}$ tym zakresie jakie występują $\mathrm{w}$ przebadanych urzędach oraz zaprezentowano możliwe do zastosowania 
Stowa

kluczowe: $\quad$ orientacja na klienta, administracja publiczna, system zarządzania jakościa.

\section{Literature}

1. Bowman J. S., Hellein R. (1998), Total Quality Management in Florida: Implementation in State Agencies, "Public Administration Quarterly", Vol. 22, No. 1.

2. Bugdol M. (2008), Zarzadzanie jakością w urzędach administracji publicznej, Wyd. Diffin, Kraków.

3. Donnelly M., Dalrymple J. F., Wisniewski M., Curry A. C. (1995), The portability of the SERVQUAL scale to the public sector, w: G. K. Kanji, Total Quality Management: Proceedings of the First World Congress, Champman \& Hall, London.

4. http:/ / www.sjp.pwn.pl (10.01.2014 - data dostępu).

5. Kancelaria Prezesa Rady Ministrów (2008), Zarządzanie Satysfakcją Klienta. Europejski Poradnik Praktyka, Warszawa, https://dsc.kprm.gov.pl/sites/ default/ files/pliki/111.pdf (10.01.2014 - data dostępu).

6. Konarzewska-Gubała E. (red.) (2006), Zarządzanie przez jakość. Koncepcje, metody, studia przypadków, Wyd. Akademii Ekonomicznej we Wrocławiu, Wrocław.

7. Kopaliński W. (1990), Stownik wyrazów obcych i zwrotów obcojęzycznych, Wyd. 20. Wyd. Wiedza Powszechna, Warszawa.

8. Otenyo E. E., Lind N. S. (2006), Comparative Public Administration: the Essentials Readings, "Research in Public Policy Analysis and Management", Vol. 15.

9. Robertson R., Ball R. (2002), Innovation and Improvement in the Delivery of Public Services: The Use of Quality Management Within Local Government in Canada, "Public Organization Review", No. 2.

10. Wawak T. (1998), Wdrażanie Total Quality Management (TQM) w urzędach administracji samorządowej - doświadczenia Małopolskiego Programu Promocji Jakości, ABC Jakości, "Quality Review”, nr 1(13).

11. Wolniak R., Skotnicka-Zasadzień B. (2009), Wykorzystanie metody Servqual do badania jakości ustug w administracji samorzadowej, Wyd. Politechniki Śląskiej, Gliwice.

12. Zawicki M., Mazur S., Bober J. (ed.) (2004), Zarządzanie w samorzadzie terytorialnym. Najlepsze praktyki, Wyd. Małopolskiej Szkoły Administracji Publicznej Akademii Ekonomicznej w Krakowie, Kraków. 
13. Zawicki M., Mazur S. (red.) (2004), Analiza instytucjonalna urzędu gminy: przewodnik dla samorząów, Wyd. Małopolskiej Szkoły Administracji Publicznej Akademii Ekonomicznej w Krakowie, Kraków.

14. Norma PN-EN ISO 9001:2009. Systemy zarządzania jakością. Wymagania, Polski Komitet Normalizacyjny, Warszawa.

15. Norma PN-EN ISO 9000:2006. Systemy zarządzania jakością. Podstawy $i$ terminologia, Polski Komitet Normalizacyjny, Warszawa.

16. Norma PN-EN ISO 9004:2001. Systemy zarządzania jakością. Wytyczne doskonalenia funkcjonowania, Polski Komitet Normalizacyjny, Warszawa.

17. Norma PN-EN ISO 9004:2010. Zarzadzanie ukierunkowane na trwaty sukces organizacji. Podejście wykorzystujace zarzadzanie jakościa, Polski Komitet Normalizacyjny, Warszawa.

18. Ustawa z dnia 14 czerwca 1960r., Kodeks Postępowania Administracyjnego, Dz.U. 1960.30.168, tekst jednolity z późniejszymi zmianami, http://isap. sejm.gov.pl/DetailsServlet? id=WDU19600300168 ( 10.01.2014 - data dostępu). 